\title{
Chemotaxonomic Study Based on the Variation of Quinone Compounds in the Heartwood of Javanese Teak Using GC-MS
}

\author{
Ganis Lukmandaru \\ Department of Forest Product Technology, \\ Faculty of Forestry, \\ Universitas Gadjah Mada, \\ Indonesia
}

\section{Introduction}

Teak that often appears in Java is one of the species most associated with the Javanese since ancient times. Teak is generally classified as a fancy wood and has also been used as a general purpose of timber. This tree grows throughout the island of Java beginning in easternmost Java (Banyuwangi, East Java Province) and ending in Sukabumi, West Java Province to the west.

Past research has confirmed that many quinones are present in teak heartwood (Sandermann and Simatupang 1966, Windeisen et al. 2003, Lukmandaru and Takahashi 2009). It is also proved that the quinone and its derivatives exhibit antitermitic activities (Sandermann and Simatupang 1966; Rudman and Gay, 1961). It is reported that the composition of these quinones vary with tree age (Lukmandaru and Takahashi 2009; Lukmandaru 2009), site and tree type (Sandermann and Simatupang 1966; Windeisen et al. 2003). This study investigated the variations in quinone constituents of teak (tectoquinone, deoxylapachol, isodeoxylapachol, lapachol, and tectol) and chemotaxonomic study based on the quinones and other related components.

\section{Materials and method}

\subsection{Sample material}

The tree samples were collected from three provinces, West Java (Purwakarta region, 32 trees), Jogjakarta (Gunungkidul region, 13 trees) and Central Java (Randublatung region, 42 trees). Those three regions (Fig. 1) have been known to produce teak trees annually in considerable amount. The condition of the sites and tree characteristics are described in Table 1. The wood from the base part from two opposite radii of the outer heartwood were converted into wood powder (40-60 mesh) and were then combined to form a single sample for further analysis. 


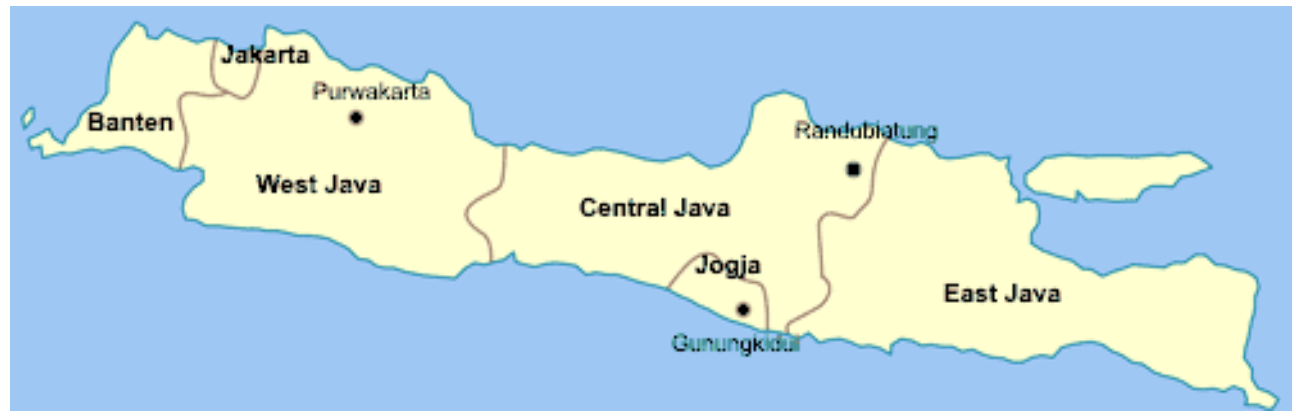

Fig. 1. Map of the island of Java, Indonesia. Teak tree samples were taken from three regions: Purwakarta, Randublatung and Gunungkidul.

\begin{tabular}{|c|c|c|c|}
\hline Factor & Purwakarta & Randublatung & Gunungkidul \\
\hline Origin/type & Plantation forest & Plantation forest & Community forest \\
\hline Province & West Java & Central Java & Jogjakarta \\
\hline Altitude (m) & 110 & 140 & 270 \\
\hline Soil type & $\begin{array}{l}\text { Latosol, loamy } \\
\text { sand }\end{array}$ & $\begin{array}{c}\text { Humous margalitic, } \\
\text { loamy sand }\end{array}$ & $\begin{array}{c}\text { Black calcareous, } \\
\text { loam }\end{array}$ \\
\hline $\begin{array}{l}\text { Annual rainfall range } \\
(\mathrm{mm})\end{array}$ & $1200-1800$ & $1300-2000$ & $1400-1800$ \\
\hline Temperature range $\left({ }^{\circ} \mathrm{C}\right)$ & $22-28$ & $20-34$ & $22-36$ \\
\hline $\begin{array}{l}\text { Relative humidity range } \\
(\%)\end{array}$ & $76-80$ & $70-74$ & $68-72$ \\
\hline Number of samples & 32 & 42 & 13 \\
\hline $\begin{array}{l}\text { Diameter breast height } \\
\text { range }(\mathrm{cm})\end{array}$ & $39-137$ & $23-83$ & $25-38$ \\
\hline
\end{tabular}

Table 1. Description of the sampling and sites.

\subsection{Analysis of extractive components}

Wood powder (about $2 \mathrm{~g}$ ) were extracted using a soxhlet apparatus with ethanol-benzene $(1: 2, \mathrm{v} / \mathrm{v})$ for 8 hours. After evaporation of the solvent, the extracts (concentration of 100 $\mathrm{mg} / \mathrm{mL}$ ) were analyzed using GC (Hitachi Model G-3 500), NB-1 bonded capillary 30m. Operation temperature was $120-300^{\circ} \mathrm{C}$ with a heating rate of $4^{\circ} \mathrm{C} / \mathrm{min}$ and held at $300^{\circ} \mathrm{C}$ for $15 \mathrm{~min}$. Injector and detector temperatures were set at $250^{\circ} \mathrm{C}$. Helium was used as the carrier gas, the split ratio was 80:1, and the injected volume was $1.0 \mu \mathrm{L}$.

The identification of components was based on a comparison between authentic components, references (Windeisen et al. 2003; Lemos et al. 1999; Perry et al. 1991), and GCMS analysis results. The following authentic components were used: tectoquinone (25753-31 Kanto Chemical), lapachol (142905 Sigma-Aldrich), 2-hydroxymethyl anthraquinone (1724159-7 Acros Organics), squalene (37309-30 Kanto Chemical), and palmitic acid (32016-30 Kanto Chemical). Mass spectrometry measurements were obtained from GC-MS analysis on a Shimadzu QP-5000 with operation conditions being similar to GC analysis. The MS operating parameters were temperature ionization voltage of $70 \mathrm{eV}$, transfer line temperature at $250^{\circ} \mathrm{C}$, and scan range of $50-500$ atomic mass unit. 


\subsection{Statistical analysis}

SPSS 10.0 version with Windows was used for principal component analysis and discriminant analysis.

\section{Results and discussion}

Fig. 2 shows the gas chromatogram of the ethanol-benzene extracts in the outer heartwood. Nine constituents, namely, deoxylapachol, palmitic acid, lapachol, isodeoxylapachol, tectoquinone, unknown compound 1 (UN1), unknown compound 2 (UN2), squalene, and tectol were detected. The peaks 1 and 4 were provisionally assigned as deoxylapachol and its isomer (Perry et al., 1991;Windeisen et al., 2003) due to the almost identical mass spectra of the two compounds (Lukmandaru and Takahashi, 2009). The molecular masses of unidentified compound 1 (UN1) and 2 (UN2) were found to be m/e (base peak) $=244$ and 242 , respectively. On the basis of their chemical structures, the quinones were from naphtaquinone (lapachol, desoxylapachol and its isomer), anthraquinone (tectoquinone), as well as naphtaquinone dimer (tectol). Table 2 summarizes the composition of components determined by capillary gas chromatography and relative contents of the constituents for 87 typical individuals of teak from 3 habitats. The contents of these nine constituents showed wide variations among individuals and habitats. Triterpene squalene was generally the most abundant component in ethanol-benzene soluble extracts (varied from 6 - $65 \%$ ) while the quinone fraction ranged from 15 to $64 \%$.

\begin{tabular}{|c|c|c|c|c|c|c|c|c|c|}
\hline \multirow[b]{2}{*}{ Components } & \multicolumn{3}{|c|}{ Purwakarta $(n=32)$} & \multicolumn{3}{|c|}{ Randublatung $(n=42)$} & \multicolumn{3}{|c|}{ Gunungkidul $(n=13)$} \\
\hline & Min. & $\operatorname{Max}$ & $\begin{array}{l}\text { Average } \\
\text { (St. dev.) }\end{array}$ & Min. & Max. & $\begin{array}{l}\text { Average } \\
\text { (St. dev.) }\end{array}$ & Min. & Max. & $\begin{array}{l}\text { Average } \\
\text { (St. dev.) }\end{array}$ \\
\hline Deoxylapachol & 0 & 26.79 & $\begin{array}{c}6.65 \\
(7.95)\end{array}$ & 0 & 17.09 & $\begin{array}{c}3.44 \\
(3.97)\end{array}$ & 0 & 23.05 & $\begin{array}{c}2.90 \\
(6.60)\end{array}$ \\
\hline Palmitic acid & 0.49 & 3.34 & $\begin{array}{c}1.34 \\
(0.60)\end{array}$ & 0 & 10.45 & $\begin{array}{c}2.03 \\
(1.67)\end{array}$ & 0 & 13.98 & $\begin{array}{c}3.35 \\
(3.41)\end{array}$ \\
\hline Lapachol & 0 & 12.92 & $\begin{array}{c}4.25 \\
(4.06)\end{array}$ & 0 & 17.42 & $\begin{array}{c}3.37 \\
(4.10)\end{array}$ & 0 & 14.03 & $\begin{array}{c}4.39 \\
(3.87)\end{array}$ \\
\hline Isodeoxylapachol & 0 & 13.44 & $\begin{array}{c}5.17 \\
(3.08)\end{array}$ & 2.15 & 13.78 & $\begin{array}{c}5.71 \\
(2.37)\end{array}$ & 0 & 25.94 & $\begin{array}{c}6.05 \\
(6.66)\end{array}$ \\
\hline Tectoquinone & 4.07 & 51.71 & $\begin{array}{c}14.61 \\
(10.46)\end{array}$ & 2.16 & 21.18 & $\begin{array}{c}8.05 \\
(5.28)\end{array}$ & 3.17 & 23.92 & $\begin{array}{l}11.31 \\
(6.24)\end{array}$ \\
\hline UN1 & 0 & 4.00 & $\begin{array}{c}0.48 \\
(0.88)\end{array}$ & 0 & 11.24 & $\begin{array}{c}1.75 \\
(2.63)\end{array}$ & 0 & 7.28 & $\begin{array}{c}1.81 \\
(1.96)\end{array}$ \\
\hline UN2 & 0 & 9.80 & $\begin{array}{l}1.90 \\
(2.20)\end{array}$ & 0 & 3.82 & $\begin{array}{c}1.10 \\
(0.80)\end{array}$ & 0 & 11.32 & $\begin{array}{c}2.16 \\
(3.02)\end{array}$ \\
\hline Squalene & 7.59 & 62.60 & $\begin{array}{c}41.89 \\
(12.03)\end{array}$ & $\begin{array}{c}12.4 \\
5\end{array}$ & 65.23 & $\begin{array}{c}42.75 \\
(14.66)\end{array}$ & 6.86 & 54.02 & $\begin{array}{c}26.29 \\
(15.10)\end{array}$ \\
\hline Tectol & 2.25 & 28.91 & $\begin{array}{l}10.71 \\
(5.92)\end{array}$ & 3.34 & 17.99 & $\begin{array}{c}9.71 \\
(2.86)\end{array}$ & 0 & 20.34 & $\begin{array}{c}6.75 \\
(6.22)\end{array}$ \\
\hline
\end{tabular}

Note : UN : unknown compound,

Table 2. The relative contents of ethanol-benzene soluble components in the outer heartwood of Teak in three habitats. 


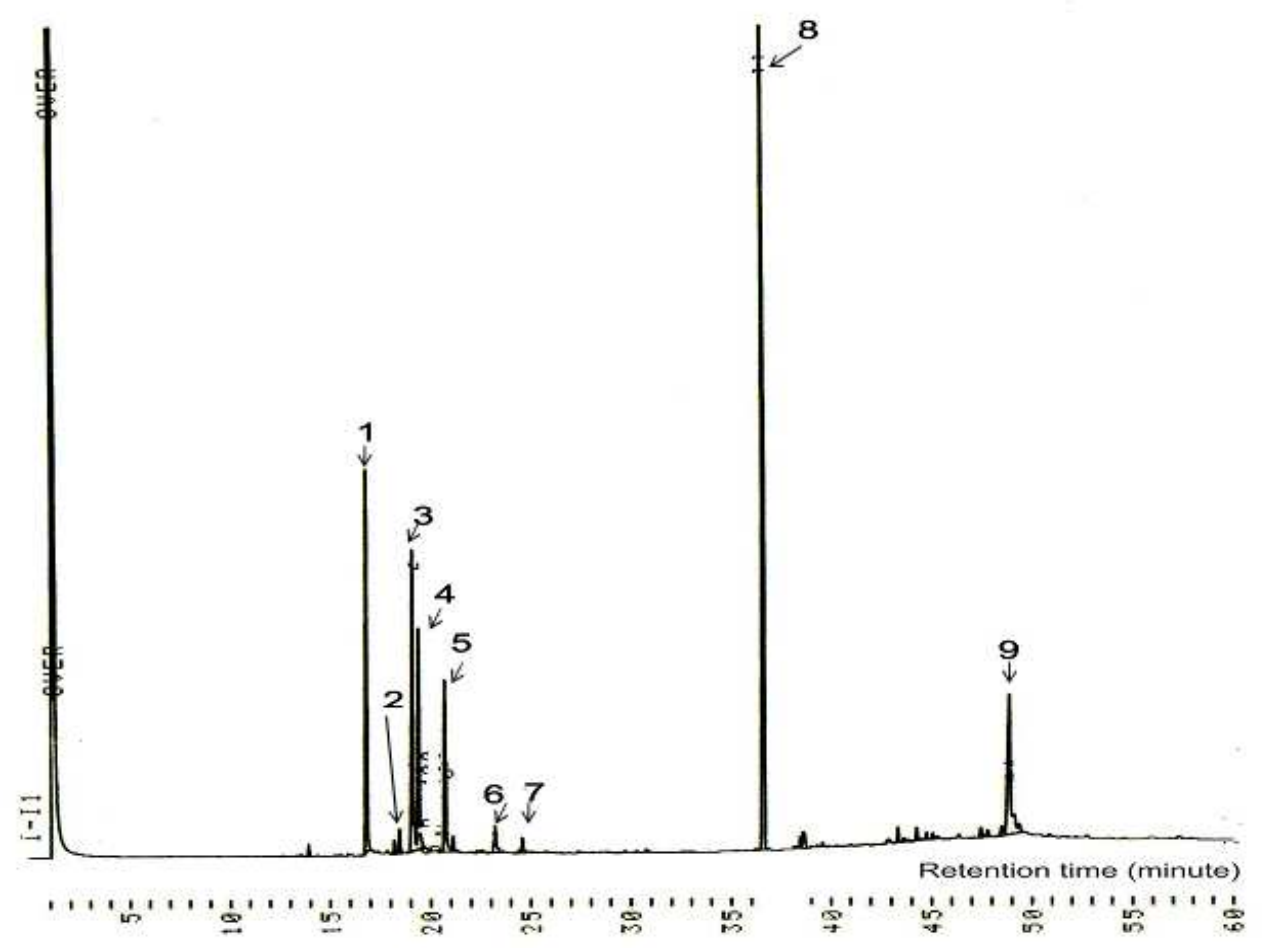

Fig. 2. Gas chromatogram of the ethanol-benzene extract from the teak outer heartwood. Nine major compounds are detected : peak 1 and $4=$ desoxylapachol and its isomer; peak 2 = palmitic acid; peak $3=$ lapachol; peak $5=$ tectoquinone; peak $6=$ unidentified compound 1 ; peak $7=$ unidentified compound 2 ; peak $8=$ squalene; and peak $9=$ tectol.

To evaluate the relationship between the detected nine constituents and 87 individuals, principal component analysis was conducted. The result of the principal component showed that the individuals can be classified into three main groups (Table 3). First principal component were represented by palmitic acid, isodeoxylapachol, and tectol as the principal components. Tectoquinone, UN2, and squalene were representative of the second principal component. As the isodeoxylapachol and tectoquinone contents showed relatively high values, the content of those compounds were examined for each individual. The isodeoxylapachol histogram is shown in Fig. 3. It showed a curve that the there was no individual with content from 10 to $12 \%$ and from 14 to $24 \%$ individuals. This curve can be divided into two types with high content (over 6\%: 37 individuals with average content of $8.41 \%$ and standard deviation of $3.46 \%)$, and low content (0-6\%: 50 individuals with average content of $3.46 \%$ and standard deviation of $1.53 \%$ ) of isodeoxylapachol. 


\begin{tabular}{lccc}
\hline Constituents & $\begin{array}{c}\text { First principal } \\
\text { component }\end{array}$ & $\begin{array}{c}\text { Second principal } \\
\text { component }\end{array}$ & $\begin{array}{c}\text { Third principal } \\
\text { component }\end{array}$ \\
\hline Deoxylapachol & -0.07 & -0.30 & 0.61 \\
Palmitic acid & 0.75 & 0.10 & -0.10 \\
Lapachol & -0.14 & 0.06 & 0.63 \\
Isodeoxylapachol & $\mathbf{0 . 7 8}$ & -0.10 & 0.24 \\
Tectoquinone & 0.08 & $\mathbf{0 . 8 1}$ & -0.30 \\
UN1 & 0.17 & -0.01 & 0.72 \\
UN2 & -0.20 & 0.84 & 0.01 \\
Squalene & -0.54 & -0.64 & -0.40 \\
Tectol & 0.66 & 0.05 & -0.16 \\
& & & \\
\hline Cumulative distribution & 0.24 & 0.45 & 0.62 \\
\hline
\end{tabular}

Note : UN : unknown compound

Table 3. Factor loadings of nine constituents in principal component analysis

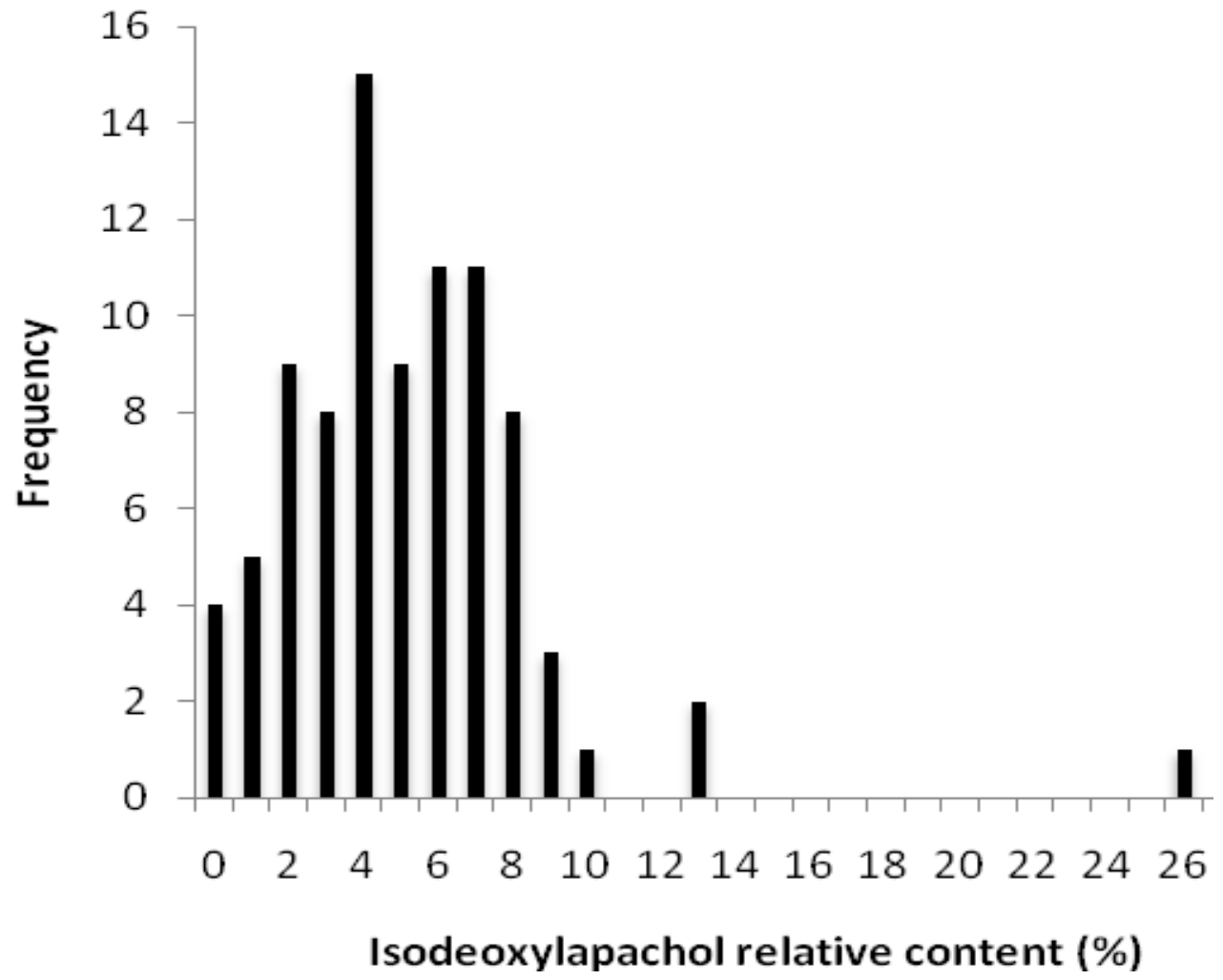

Fig. 3. Histogram of isodeoxylapachol relative content in the outer heartwood of Teak 
For tectoquinone, there was no individual with content from 24 to $28 \%$ as well as from 44 to $48 \%$ (Fig. 4 ) but the individuals could be divided into two groups with low contents $(0-16 \%$ : 72 individuals with an average content of $8.25 \%$ and a standard deviation of $4.05 \%$ ), and high contents (over $16 \%$ : 15 individuals with an average content of $24.45 \%$ and a standard deviation of $9.71 \%)$. On the basis of this result, we classified the 15 individuals with high tectoquinone contents as TypeT, the 37 individuals with high isodeoxylapachol contents as TypeI. Since two constituents were found in some individuals, we classified the individuals according to whether they contain only one of the constituents or two of them. There were six individuals only containing with high isodesoxylapachol and tectoquinone levels as well as the 42 individuals with low isodesoxylapachol and tectoquinone levels as TypeL.

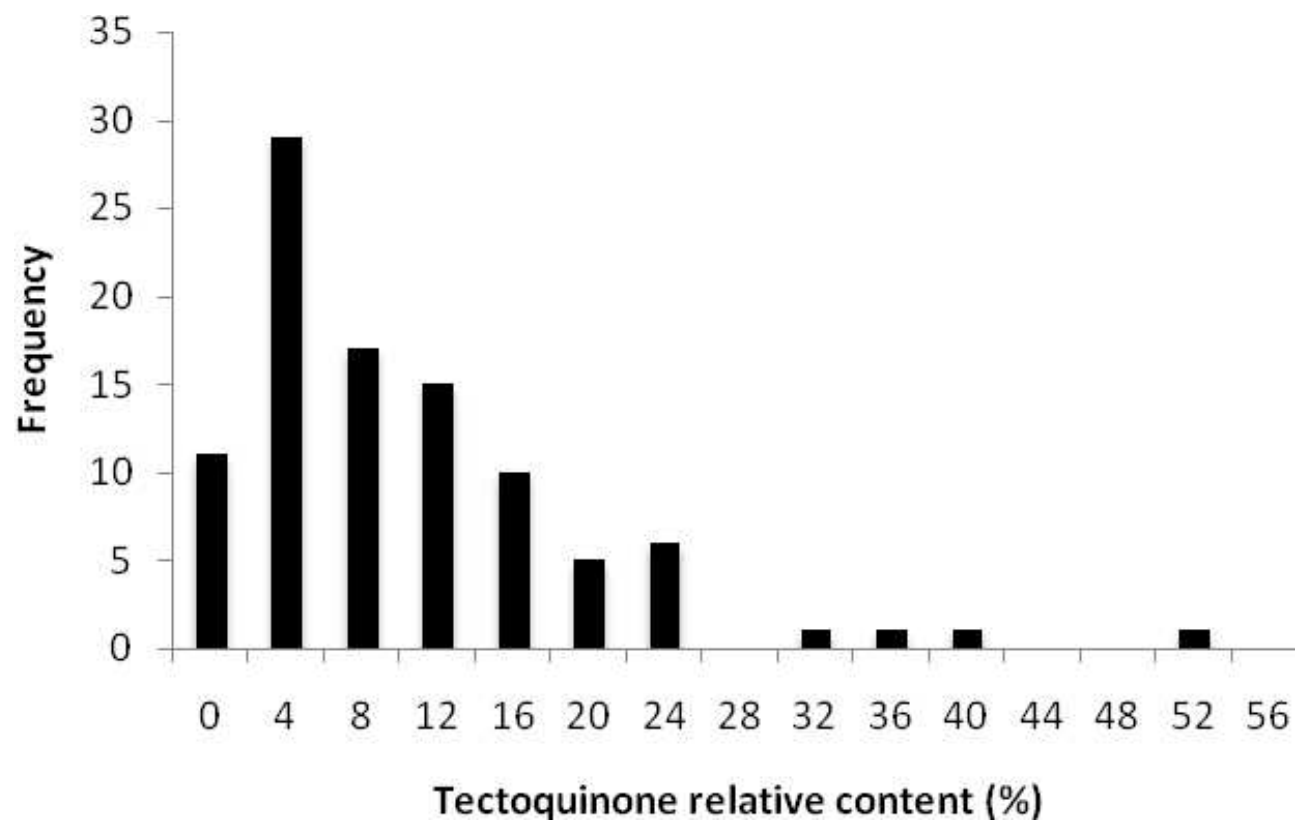

Fig. 4. Histogram of tectoquinone relative content in the outer heartwood of Teak

On the basis of geographical distribution (Table 4), TypeI accounted for $42.5 \%$ (37/87) of the population and equally distributed in both Purwakarta and Randublatung regions. It is also noted that in seven out of 13 tree samples taken from community forest in Gunungkidul region were classified as TypeI. TypeT accounted for $17.24 \%(15 / 87)$ of the population. This type was particularly minor in Randublatung region (9.52\%). TypeL which can produce small amounts of both isodesoxylapachol and tectoquinone, accounted for $48.2 \%$ (42/87) of the population. This type was the most common in Randublatung region (57.1\%). It is noticed that from six individuals containing with high isodesoxylapachol and tectoquinone, only one individual was found in Purwakarta region. 


\begin{tabular}{lcccc}
\hline Region & Number of individuals & \multicolumn{4}{c}{ Classification by quinone components } \\
& & $\mathrm{T}$ & $\mathrm{I}$ & $\mathrm{L}$ \\
\hline Purwakarta & 32 & 8 & 13 & 13 \\
Gunungkidul & 13 & 3 & 7 & 5 \\
Randublatung & 42 & 4 & 17 & 24 \\
& & & & \\
\hline Total & 87 & 15 & 37 & 42 \\
\hline
\end{tabular}

Note : UN : unknown compound; $\mathrm{T}$ : tectoquinone relative content over $16 \%$; I : isodeoxylapachol relative content over $6 \%$; $\mathrm{L}$ : tectoquinone relative content $0-16 \%$ and isodeoxylapachol relative content $0-6 \%$

Table 4. Frequency of individuals classified based on contents of quinone components

As the final step, discriminant analysis was used. The discriminant ratio was $90.8 \%(79 / 87)$. Only 2 individuals of TypeL was discriminated as TypeI, whereas only 3 individuals of TypeL were discriminated incorrectly as TypeI. Teak individuals can be thus classified into three types (TypeI, TypeT, and TypeL) on the basis of the contents of quinone constituent (isodeoxylapachol and tectoquinone) and also their distribution corresponding to variations in the contents. For more comprehensive investigations, the subsequent works should be conducted with larger samples including plantation teak trees from East Java as well as from community forests that scattered in the island of Java.

\section{Conclusions}

This is the first report on the chemotaxonomical study of teak heartwood. The tree samples were collected from three regions, Purwakarta, Gunungkidul, and Randublatung, for a total of 87 individuals. Based on the principal component analysis, three types (T,I and L) can be obtained from the relative content of isodeoxylapachol and tectoquinone. TypeT, TypeI and TypeL refers the heartwood with high tectoquinone (over $16 \%$ ); high isodeoxylapachol (over $6 \%$ ); and low tectoquinone - isodeoxylapachol relative contents, consecutively. Based on geographical distribution, it is found that TypeI is the major type in Gunungkidul while TypeL is the most abundant in Randublatung.

\section{Acknowledgement}

The author thanks to Professor Koetsu Takahashi (Yamagata University, Japan) for facilitating this research. Assistance with statistical analysis was provided by Mr. Nawari. The samples were supplied by Mr. Trisno Aji (Perhutani Enterprise) and Mr. Mufti Wibowo (Brebes Forest Service).

\section{References}

Lemos TG, Costa SM, Pessoa OL, \& Braz-Filho R. 1999. Total assignment of ${ }^{1} \mathrm{H}$ and ${ }^{13} \mathrm{C}$ NMR spectra of tectol and tecomaquinone. Magnetic Resonance in Chemistry 37:908-911.

Lukmandaru G. 2009. Chemical and colour properties in teak heartwood from three different ages. Journal of Tropical Wood Science and Technology7:1-7. (in Indonesian). 
Lukmandaru G and Takahashi K. 2009. Radial distribution of quinones in plantation teak (Tectona grandis L.f.). Annals of Forest Science 66:605 p1 - p9.

Perry NB, Blunt JW, and Munro MHG. 1991. A cytotoxic and antifungal 1,4 naphtaquinone and related compounds from a New Zealand brown alga, Landsburgia quercifolia. Journal of Natural Product 54:978-985.

Rudman P and Gay FJ. 1961. The causes natural durability in timber part VI. Measurement of anti-termite properties of anthraquinones from Tectona grandis L.f. by rapid semimicro method. Holzforschung 15: 117-120.

Sandermann W and Simatupang MH. 1966. On the chemistry and biochemistry of teakwood (Tectona grandis L. fil). Holz als Roh-und Werkstoff 24: 190-204.

Windeisen E, Klassen A, and Wegener G. 2003. On the chemical characterization of plantation teakwood (Tectona grandis L.) from Panama. Holz als Roh-und Werkstoff 61:416-418. 


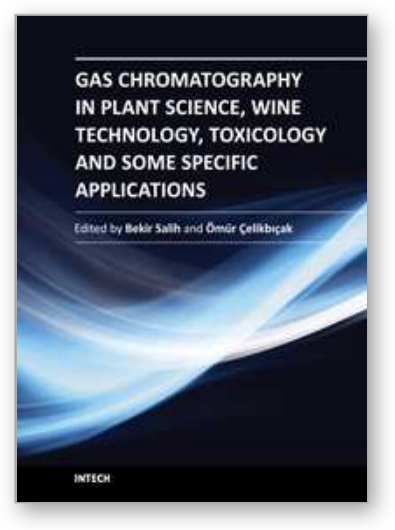

\author{
Gas Chromatography in Plant Science, Wine Technology, \\ Toxicology and Some Specific Applications \\ Edited by Dr. Bekir Salih
}

ISBN 978-953-51-0127-7

Hard cover, 346 pages

Publisher InTech

Published online 29, February, 2012

Published in print edition February, 2012

The aim of this book is to describe the fundamental aspects and details of certain gas chromatography applications in Plant Science, Wine technology, Toxicology and the other specific disciplines that are currently being researched. The very best gas chromatography experts have been chosen as authors in each area. The individual chapter has been written to be self-contained so that readers may peruse particular topics but can pursue the other chapters in the each section to gain more insight about different gas chromatography applications in the same research field. This book will surely be useful to gas chromatography users who are desirous of perfecting themselves in one of the important branch of analytical chemistry.

\title{
How to reference
}

In order to correctly reference this scholarly work, feel free to copy and paste the following:

Ganis Lukmandaru (2012). Chemotaxonomic Study Based on the Variation of Quinone Compounds in the Heartwood of Javanese Teak Using GC-MS, Gas Chromatography in Plant Science, Wine Technology, Toxicology and Some Specific Applications, Dr. Bekir Salih (Ed.), ISBN: 978-953-51-0127-7, InTech, Available from: http://www.intechopen.com/books/gas-chromatography-in-plant-science-wine-technology-toxicologyand-some-specific-applications/chemotaxonomic-study-based-on-the-variation-of-quinone-compounds-in-theheartwood-of-javanese-teak-u

\section{INTECH}

open science | open minds

\author{
InTech Europe \\ University Campus STeP Ri \\ Slavka Krautzeka 83/A \\ 51000 Rijeka, Croatia \\ Phone: +385 (51) 770447 \\ Fax: +385 (51) 686166 \\ www.intechopen.com
}

\author{
InTech China \\ Unit 405, Office Block, Hotel Equatorial Shanghai \\ No.65, Yan An Road (West), Shanghai, 200040, China \\ 中国上海市延安西路65号上海国际贵都大饭店办公楼405单元 \\ Phone: +86-21-62489820 \\ Fax: +86-21-62489821
}


(C) 2012 The Author(s). Licensee IntechOpen. This is an open access article distributed under the terms of the Creative Commons Attribution 3.0 License, which permits unrestricted use, distribution, and reproduction in any medium, provided the original work is properly cited. 